\title{
Earnings Management by Non-Profit Organisations: Evidence from UK Charities
}

\author{
Tam Nguyen $^{\mathrm{a}}$ and Teerooven Soobaroyen ${ }^{\mathrm{b}}$ \\ PRE-PRINT VERSION - ACCEPTED IN AUSTRALIAN ACCOUNTING REVIEW
}

${ }^{a}$ Nottingham University Business School (Corresponding author)
University Of Nottingham
Jubilee Campus
Wollaton Road
Nottingham, NG8 2BB
Email: tamnh0110@gmail.com
Phone: +44 1158467073
${ }^{\text {b} E s s e x ~ B u s i n e s s ~ S c h o o l ~}$
University of Essex
Wivenhoe Park, Colchester
CO4 3SQ, UK
Email: tsooba@essex.ac.uk
Phone: +44 1206874015

\section{Author biography}

Dr Tam Nguyen is a chartered accountant (ACCA and CIPFA, UK) and qualified accountant (CPA Australia, CPA Vietnam), Assistant Professor in accounting at University of Nottingham. His research work and interests focus on charity accounting, accountability and governance.

Dr Teerooven Soobaroyen is a Professor of Accounting at Essex Business School. His research interests are in the area of social and environment accounting, corporate governance, and nonprofit accounting \& accountability. He has published in internationally recognised journals such as Accounting, Auditing and Accountability Journal, Journal of Business Ethics, Accounting and Business Research, Business \& Society, Accounting Forum, Corporate Governance: An International Review, Financial Accountability and Management, Advances in Accounting and Qualitative Research in Accounting and Management. Professor Soobaroyen is the current Chair of the British Accounting and Finance Association (BAFA) Accounting and Finance in Emerging Economies (AFEE) Special Interest Group and Secretary of the African Accounting and Finance Association (AAFA).

Acknowledgements: We are grateful for comments and feedback from participants of European Accounting Association Annual Congress (2015) in Glasgow, Scotland; British Accounting and Finance Association- South Western Area Group conferences (2014) in Cardiff, Wales. 


\section{Earnings Management by Non-Profit Organisations: Evidence from UK Charities}

\section{Summary at a glance ( 50 words)}

This study aims to investigate whether UK charities are engaged in earnings management. We found that UK charities use discretionary accruals to drive their financial results toward a zero level and there is an association between leverage and earnings management practice.

Furthermore, earnings management is influenced by the organisational size. 


\begin{abstract}
Informed by stakeholder theory and resource dependence theory, this paper investigates whether United Kingdom (UK) charities are engaged in earnings management practices. Based on a sample of 1414 charities over a five-year period (2008-2012) this study firstly finds that UK charities use discretionary accruals to drive their financial results toward a zero surplus/deficit; this result also reveals that the distribution of reported earnings around zero is prevalent amongst UK charities. In addition, in contrast to prior findings, the empirical results point to a significant association between leverage and earnings management behaviour by charities. Lastly, this study also finds that the practice of earnings management is influenced by non-profit organizational size.
\end{abstract}

Keywords: Earnings management; non-profit organisations; charities; leverage; stakeholder theory; resource dependence theory. 


\section{Introduction}

Earnings management remains one of the crucial research areas of accounting practice. Much of the work has analysed the extent of earnings management, techniques used to manage earnings, motivations for managing earnings, and the consequences of earnings management, as well as policy recommendations aimed at curbing earnings management activities in the for-profit sector (Schipper, 1989; Jones, 1991; Burgstahler and Dichev, 1997; Healy and Wahlen, 1999; Dechow and Skinner, 2000; Roychowdhury, 2006; Shubita, 2012; Walker, 2013; Miloud, 2014). However, there has been relatively less scrutiny in the case of non-profit organizations (Leone and Van Horn, 2005; Ballantine et al., 2007; Verbruggen and Christiaens, 2012; Jegers, 2013). Consequently, this paper focuses on the financial accounting practices of non-profit organizations (NPOs) in the UK, with specific attention to the practice of earnings management.

Admittedly, a limited number of empirical studies has already found evidence of earnings management (also financial disclosure management and/or accounting manipulation) in non-profit settings (Leone and Van Horn, 2005; Jones and Roberts, 2006; Ballantine et al., 2007; Verbruggen and Christiaens, 2012; Jegers, 2013; Boterenbrood, 2014; Vermeer et al., 2014). In the specific case of the UK, a research gap exists since there has been no comprehensive study of earnings management in UK charities ${ }^{1}$, and the closest relevant study (Ballantine et al. (2007) focused only on quasi-public bodies (English NHS Trusts). As in the case of several EM studies in other countries (Yetman, 2001; Leone and Van Horn, 2005), the focus has remained on idiosyncratic settings (such as hospitals) rather than on the broader constituency of larger NPOs that have adopted accruals-based accounting conventions. The case of the UK is of particular relevance in terms of its extensive attempts in developing and implementing a robust regulatory framework and a common set of accounting practices, typified by the numerous iterations of the Statement of Recommended Practice (Charity 
Commission, 2005), resulting from concerns about accountability, transparency and confidence in the activities of the charitable sector (Hyndman and McMahon, 2010). While Verbruggen and Christiaens (2012)'s study explored the data of Belgian non-profits that are highly subsidized by the government and their research had a limitation in terms of testing the earnings management differences among specific sectors of Belgian NPOs, this study focuses on UK charities which generate different sources of funding from private donors and from commercial activities. In addition, this paper uses a large dataset covering numerous charitable sectors. Our study is also motivated by reports from the UK Charity Commission (2013a, 2014) stating that there were more than 3,000 compliance cases over a period of two years; of which accounting issues were one of the most common problems dealt with by the regulator, for example, some charities ${ }^{2}$ were accused of providing misleading financial information. This leads to our main research questions: Do UK charities engage in earnings management practices?

From a theoretical standpoint, prior NPO-related studies have generally applied agency theory (Krishnan et al. 2006, Jegers 2010, Jegers 2013) to examine the extent of earnings management practices in such settings. This suggests that earnings management is encouraged by self-interested agents. However, this paper argues that broader motivations are at play in terms of the role accounting information plays in delivering accountability, transparency, reputation and confidence to a wide array of stakeholders. Furthermore, NPOs' access to funds in the form of voluntary income, charitable income and non-financial resources (e.g. donations in kind, volunteer labour) is notoriously volatile, implying continuous and significant efforts in managing external relationships and dependencies (Connolly and Hyndman 2013). In this regard, stakeholder theory and resource dependence theory are adopted as the framework underpinning the likely motivation and determinants of earnings management by charities. Empirically, this study relies on data from 1414 charities 
selected on a stratified basis in relation to size (total income) and classified in eleven subsectors of activities (based on the International Classification of Non-Profit Organisation) over a five-year period (2008-2012). The results firstly suggest that UK charities use discretionary accruals in order to drive their financial results toward a zero surplus/deficit. This result is consistent with the frequency distribution of reported earnings, which shows that a number of charities with negative unmanaged deficits have reported little surpluses after applying discretionary accruals. Secondly, the empirical results reveal a negative association between leverage and earnings management behaviour. Thirdly, the results show that organizational size has an influence on earnings management practice, whereby larger organizations are less likely to be involved in earnings management practice. This paper also studies the impact of alternative types of resources (different source of income) on earnings management practice but the results are not significant.

This paper contributes to the literature in several ways. First, it provides evidence from a large and diverse UK sample that charities appear to apply discretionary accruals to manage their accounting results. Although there is no specific requirement to achieve a breakeven position, charities are likely to complete the year with a little surplus (the difference between total income and total expenses). This finding is important because potential donors and funders partly rely on accounting information to underpin their decision to provide financial and non-financial support to charities. Relatedly, central government and local authorities may be led into misallocating their service contracts to charities due a reliance on accounting information to gauge the sustainability of the service provider. In addition, the finding is important for the main UK charity regulator (Charity Commission) in the monitoring of charities and to enhance their public accountability. Second, whilst the academic and practitioner literature (for example, Connolly and Hyndman (2001), Hyndman and McMahon (2010) has debated extensively on the development and implementation of 
appropriate accounting standards in the UK charitable sector (the Statement of Recommend Practice) with a view to improving accountability, transparency, efficiency and effectiveness, our findings have an important implication for policy in that the introduction of accrualsbased accounting regulation, as in the case of private sector settings, does provide the opportunity for discretionary accruals. Finally, the paper also contributes to the theoretical perspective on earnings management practices by considering the relevance of stakeholder theory and resource dependence theory to underpin the study of the factors underlying the extent of such practices by non-profit organisations (Van Puyvelde et al., 2012).

The paper is structured as follows. The next section reviews the institutional setting and the literature on earnings management in NPOs, followed by the theoretical framework and hypotheses in Section 3. The data and models used to measure earnings management are presented in Section 4. Section 5 describes and analyses the empirical results and Section 6 concludes the paper with a discussion of the findings, implications, limitations and propositions for further work on earnings management practices by NPOs.

\section{Institutional settings and review of prior literature}

\section{a. UK charity settings and regulatory framework}

By June 2017 there were over 166,000 registered charities in the England and Wales with a total annual income of approximately $£ 74$ billion $^{3}$. In 2015 , the sector contributed about $£ 12.2$ billion in terms of gross value added, equivalent to almost $0.9 \%$ of the gross value added of all industries in the UK and employed about 800,000 people $(2.7 \%$ of the total UK workforce) $)^{4}$.

The regulatory framework for charity accounting and reporting regulation in the UK has experienced significant development, notably since the study by Bird and Morgan-Jones (1981) who found extensive accounting inconsistencies and unclear policies by charities. Consequently, a number of Statements of Recommended Practice ${ }^{5}$ have been published and 
revised in 1988, 1995, 2000 (Connolly and Hyndman, 2001), 2005 and more recently in 2014, and supplements the accounting and reporting requirements of the Charities Act $(1960,1993$, 2006, and 2011). As stated by the Charity Commission (2014), the Statements of Recommended Practice aims to improve the quality of financial reporting by charities and increase the transparency of information about the charity's financial performance and financial position, for the benefit of a wide range of stakeholders. One of the major developments has been the adoption of accruals-based accounting, which requires charities to report their income and expenditure on the basis of occurred transactions, rather than when charities receive and/or spend cash. According to Charity Act 1993 (England and Wales) and Charities and Trustee investment Act 2005 (Scotland), since February 2005, accruals-based accounting was mandatory for all charitable companies and non-company charities with gross income exceeding $£ 100,000$ (Charity Commission, 2005). However, the application of accrual accounting may arguably provide reporting organisations with the opportunity to exploit the inherent flexibility of discretionary accruals (Verbruggen and Christiaens, 2012; Jegers, 2013), evidence of which is summarised in the following section.

\section{b. Earnings management by non-profit organisations}

The definition of earnings management in the non-profit sector has not been explicitly defined but Healy and Wahlen's (1999) definition about earnings management is generally cited in NPO studies (Ballantine et al. 2007, Verbruggen and Christiaens 2012). These authors support the view that earnings management could potentially mislead stakeholders who use financial information to assess the organisation's performance or to make grant decisions. Therefore, the terminology of earnings management covers a wider set accounting issues which may affect the quality of the financial information. Instead of using earnings management terminology, a different term ('financial disclosure management') has been used 
to describe the practice of managing accounting figures, either by using accrual accounting or discretion in cost allocation practices (Hofmann and McSwain, 2013).

Several studies in the non-profit context (Khumawala et al., 2005; Jones and Roberts, 2006; Krishnan et al., 2006; Keating et al., 2008; Tinkelman, 2009; Yetman and Yetman, 2013; Garven et al., 2016) adopt agency theory-led perspectives to argue that NPO executives may adjust accounting numbers or alter the reporting process with a view to improving the efficiency ratio (which is normally measured by the total money spent on charitable activities over total income or total expense of NPOs. A higher reported efficiency ratio is generally associated to managerial competence, which in turn could improve organisational reputation and lead to higher donations (Tinkelman, 1999). In particular, charities were found to make substantial changes to programme ratios by using joint cost allocations and misclassifying fundraising expenses (Jones and Roberts, 2006; Keating et al., 2008) or reported zero fundraising expenses although they undertook fundraising activities (Krishnan et al., 2006) in order to give the impression that donor money has been used for worthy causes or to hide potential inefficiencies in fundraising activities.

Furthermore, a number of studies contend that the motivation for NPOs to modify reported earnings may arise due to tax avoidance matters or to avoid interference from the regulator (political costs). In this respect, cost allocation and cost 'shifting' are preferable methods that have been used by a number of organisations for misreporting expenditures and adjusting earnings in order to re-allocate expenses from their tax-exempt activities to the taxable activities with a purpose of reducing tax liabilities (Yetman, 2001; Omer and Yetman, 2003; Hofmann, 2007; Omer and Yetman, 2007). NPOs are also found to report small surpluses and deficits around zero (Leone and Van Horn, 2005; Ballantine et al., 2007). They are also involved in managing accrual accounting (Verbruggen and Christiaens, 2012; Jegers, 
2013) and real earnings management activities (Eldenburg et al., 2011) in order to meet statutory obligations and government accounting regulations.

This review indicates that there is some empirical evidence of NPOs engaged in earnings management but the evidence is limited to very few countries or to specific sectors. For instance, the 'zero profit' acts as a means for NPOs to imply that they have spent all incoming resources in order to fulfil their charitable purpose as well as a signal of requiring further resources (Verbruggen and Christiaens, 2012). However, evidence of this behaviour has not been considered for the wider constituency of UK organisations, particularly in the period post-2005 following the implementation of the updated Statement of Recommended Practice (SORP, 2005), the development of guidelines for charity financial accountability and governance and monitoring activities by the Charity Commission. For larger UK charities (total income in excess of $£ 250,000$ ), there is the possibility that some items, such as depreciation or current assets, may be open to discretionary practices (Jegers, 2013). A socalled 'active' application of accrual accounting may result in an upwards or downwards movement in surplus/deficit, depending upon managerial or organisational intentions/characteristics but this also has yet to be examined in the UK context.

\section{Theoretical background and hypothesis development}

\section{a. Theoretical background}

Agency theory has typically been the dominant perspective in the NPO accounting literature (Van Puyvelde et al, 2012) but its arguably restrictive assumptions about the agent's characteristics such as self-interest, bounded rationality and risk aversion are not always applicable to NPOs. Furthermore, it is often difficult to clearly identify the ultimate owner(s) and agent (Jegers, 2013; Newton, 2015) since some NPOs do not have a 'membership' base (akin to shareholders). In effect, the 'principal-agent relationship' in the NPO sector is potentially more eclectic than in the corporate sector and actors may have a varied set of 
motivations and behaviours underlying organisational choice and policies (including the use of accounting discretion).

Consequently, we draw from stakeholder theory and resource dependence theory to conceptualise the different behaviours and motivations underlying the use (and production) of financial accounting information by NPOs. A stakeholder of an organisation is defined by Freeman (2010) as anyone who can affect or is affected by the organisation. This suggests that all groups or individuals who belong to NPOs and outsiders, with inter-relationships to the organisation can be considered as stakeholders, such as employees, customers, suppliers, banks, regulators, volunteers and beneficiaries. These stakeholders do have a direct effect on/from the organisation. To classify alternative group of stakeholders, Mitchell et al. (1997) for example proposed three stakeholder attributes: (1) the power to influence the firm, (2) the legitimacy of relationship with the firm, and (3) the urgency of claim on the firm. Depending on one, two or three attributes, the organisation identifies who is the salient stakeholder and seeks to satisfy the expectations of the key stakeholder(s) at this particular point of time. This suggests a rather flexible approach by organisations whereby accounting discretion or policies may be adopted to respond to a salient stakeholder.

According to Donaldson and Preston (1995), stakeholder theory encompasses three different viewpoints, namely descriptive/empirical, instrumental, and normative. The instrumental stakeholder theory is relied upon to identify the links between stakeholder management and the achievement of organisational objectives. The instrumental stakeholder theory is supported by many authors (Hillman and Keim 2001, Kaler 2003) in a situation when attention to a specific stakeholder can impact on the achievement of organisation's goals. This theory could this be applied to explain earnings management practice in the nonprofit sector, where NPOs operate in tandem with different stakeholders (such as donors, regulators, government, volunteers, beneficiaries), to meet stakeholder expectations, including 
the need to comply with legitimate regulations (Connolly et al. 2013). Since a number of stakeholders engage with NPOs for different interests, management might intentionally manage accounting policies and accounting figures in order to satisfy the expectations of these specific stakeholders.

For example, Tinkelman (1999) suggested that donors might be interested in the efficiency performance of NPOs since a high efficiency ratio (which might be measured by programme ratio or fundraising expense ratio, how much money have been spent on charitable activities in compare with money spent on fundraising (admin) activities) may signal that donated funds have been used appropriately; consequently, more money has been spent on charitable activities, thereby leading to more donations. In a similar vein, governments or regulators may be interested in the NPOs level of compliance as a result of increased political scrutiny and accountability towards the taxpayer (Ballantine et al. 2007). The compliance of NPOs might be demonstrated through a commitment with charitable and not for profit objectives and missions, where charities and NPOs ensure their funds and grants reach the relevant beneficiaries. Beattie and Jetty (2009) also contend that charities appear to prioritize some stakeholders (e.g. donors, regulators) when preparing financial reports, because these stakeholders have power, legitimacy and urgent claims on charities. An emphasis on salient stakeholders can also imply a relationship between those who can offer resources to organisations that are financially vulnerable or susceptible to an uncertain environment.

In addition, in line with resource dependence theory, organisations respond in specific ways when confronted to the demands of interest groups upon which the organisations depend for resources and support in order to reduce environmental uncertainty and dependence (Pfeffer and Salancik, 1978). NPOs are not an exception because they operate in such a closed relationship and 'are dependent upon continuing exchanges with the environments in which 
they operate' (Heimovics and Herman 1993: 425). NPOs are not isolated from their environment, and their operation is largely dependent upon the flow of resources from outside (Heimovics and Herman 1993). Due to increasing competition within the non-profit sector, coupled with a decline in funding and fundraising, the negative consequences of this context may lead to changes in organisational mission, culture, structures and routines (Dolnicar et al., 2008). According to the $\mathrm{NCVO}^{6}$ (2012), UK charities lost over $£ 1.3$ billion in income from government as spending cuts (around 8.8\%) materialized during financial year 2011/2012. This spending cut has severely impacted on charity operations whilst the demand for public service continues to grow, whereby 'many charities face the very real challenge of having to do more with less, and in some cases nothing' (NCVO, 2012, p. 4). This requires charities to secure other type of resources to retain their operations. To cope with those challenges and to target the inflow funds for operations, charity executives may over- or understate accounting figures in order to influence users of financial reports (Tinkelman, 1999; Buchheit and Parsons, 2006). In addition, Carpenter and Feroz (2001) suggest that organisations choose certain accounting practices not merely because these practices applications might be the rational way to account for the use of funds, but also because those methods are a socially accepted and legitimate way to account for the use of resources. As an illustration, Verbruggen et al. (2011) contends that NPOs increase their compliance to accounting regulation in cases where they rely more on governmental resources and financial loans; with a view to safeguarding the flow of resources from government.

The probability of involving in managing accounting figures in order to secure the resources can be associated to the flexibility of accounting practices, or can also arise due to the ambiguity in the treatment of accounting items (e.g. accrual accounting or joint-cost allocation). In many cases, it also appears that donors do not pay attention to detailed items 
disclosed in financial statements (Khumawala et al., 2005). Therefore, trustees and managers may be motivated in seeking a favourable bottom-line by engaging in earnings management.

\section{b. Hypothesis development}

In the aftermath of the global financial crisis, many UK charities have been facing funding gaps following the government's decision to reduce public sector spending whilst having to deal with an increasing demand for their services (National Council for Voluntary Organisations, 2012). Moreover, many charities have been affected by the global economic recession as a result of the fall in individual donations by nearly $£ 1$ billion between 2008 and 2009, while the demand for services increased by over $17 \%$. More than eight out of ten charities believe their sector is facing a crisis, and $40 \%$ of charities fear they will close down unless there is an economic improvement ${ }^{7}$. It suggested that charities have faced or are facing significant difficulties with an almost concurrent decline in their two main income resources (donations and governmental grants/contracts). Therefore, in line with the implications of stakeholder theory and resource dependence theory, this context can lead to increased pressures upon charity trustees and managers to avoid or lessen the uncertainties induced by the shortage of resources while still attempting to fulfil the charitable services expected by society and stakeholders. This may require charities to perform more effectively or demonstrate more convincingly that their performance is sufficient to satisfy the requirements from different stakeholders. Informed by findings from previous studies (Yetman, 2001; Leone and Van Horn, 2005; Jones and Roberts, 2006; Ballantine et al., 2007; Verbruggen and Christiaens, 2012; Jegers, 2013) and the theoretical framework, this study formulates three specific accounting-led hypotheses to investigate the extent to which UK charities are involved in earnings management.

First, if charities conclude the financial year with a large surplus, this is consequently transferred to an accumulated fund and brought forward to subsequent years as required by 
SORP 2005. This might negatively impact on the level of donations and the amount of fundraising in subsequent years as stakeholders realise that those charities do not need further support (Beattie and Jetty, 2009). Conversely, the reporting of a large deficit may impact on the going concern status of charities because incoming resources are not enough to cover resources expended, and trustees may experience difficulties in retaining the level of existing operations. This may in turn have an impact on the profile and reputation of the trustees, leading in some cases to the termination of executive contracts (Leone and Van Horn, 2005). Therefore, the instrumental variant of stakeholder theory suggests that charities are motivated to report accounting information that may be interpreted in a favourable light by key stakeholders, such as the zero earnings level benchmark required by legal regulators and sponsors (Ballantine et al., 2007). In a similar vein, resource dependence theory posits that the charities may be engaged in such practices to address uncertainties about future support and pre-empt a reduction in future income. Therefore, the first hypothesis is as follows:

Hypothesis 1: Reported earnings ${ }^{8}$ of UK charities (surpluses/deficits) are narrowly distributed around zero.

A zero-bottom line may seem to be a desirable operational position for many NPOs, since this figure may reflect that charities have utilised all their donated funds and grants provided by stakeholders. From a statutory perspective, charities are restricted from distributing surpluses to their 'owners' (members or trustees); rather, they exist for the aim of charitable purposes (Charities Act, 2011). They are expected to execute charitable projects on the basis of their available resources. To the best of our knowledge, however, there is no statutory requirement for UK charities to achieve a break-even, except for a regulation applicable to English NHS Hospital Trusts (Ballantine et al., 2007). Similar cases have been explored in a non-profit context (Leone and Van Horn, 2005; Ballantine et al., 2007; Verbruggen and Christiaens, 2012) and in the public sector (Ferreira et al., 2013). On the one 
hand, charities may in practice face pressures to achieve an 'ideal break-even', because if organisations operate under severe resource deficits, this not only obstructs their ability to maintain ongoing operations for the future, but also brings the risk of being forced to close down (Dodd, 2014). On the other hand, charities with excessive surpluses might be reconsidered by stakeholders in term of financial support, managerial performance evaluation and regulatory intervention (Leone and Van Horn, 2005). Previous studies (Leone and Van Horn, 2005; Ballantine et al., 2007; Verbruggen and Christiaens, 2012) found that NPOs intentionally manage their bottom line toward zero in order to achieve a target or implicitly signal their capability in financial management. The missions of NPOs and charities are not changed by time as they principally aim to achieve their charitable missions and objectives. However, due to an increasing pressure from various stakeholders (regulator, donors, government and beneficiaries), NPOs and charities may be motivated to take advantage of accrual accounting to manage the bottom line (earnings) upwards or downwards in order to achieve the zero-profit level. Therefore, the second hypothesis is as follows:

Hypothesis 2: UK charities manage earnings toward zero.

Numerous studies in the for-profit sector suggest that leverage (and the covenants underlying debt obligations) is one of the main reasons leading businesses to be involved in earnings management (Jaggi and Picheng, 2002; Saleh and Ahmed, 2005) - due to the financial and reputational costs of debt defaults or due to the opportunity to enhance service/activities to minimise negative perceptions of the organisation. Recently, Vermeer et al. (2014) found that US non-profits with high financial leverage appear to manage actuarial assumptions in order to reduce reported liabilities and expenses. Yet, results from recent studies have not been consistent and/or significant in order to be able draw conclusions about a leverage effect (Verbruggen and Christiaens, 2012; Jegers, 2013). 
In terms of the UK charity context, James (2014) reported that more than one in eight of the UK's largest charities have negative working capital (current liabilities exceeding current assets). In such circumstances the Charity Commission requires charities to provide an explanation in their annual reports, along with likely solutions to address the situation. These charities may also be investigated by the Charity Commission. In the worst cases, charities might be forced to liquidate or close down because of their inability to cover their liabilities. This contextual factor implies that charities with a higher level of liabilities will therefore face a higher burden of regulatory scrutiny. Consistent with resource dependence theory and stakeholder theory, charities may aim to deflect any regulatory intervention and preserve their positive image with funders and other resource providers. Executives and managers may consequently be keen to adjust or intentionally manage accounting figures (the reported surplus/deficits) in order to meet fund provider expectations. Alternatively, a high proportion of debts may be interpreted another way, in that UK charities are in a difficult period in terms of fundraising. In many cases charities use debt and credit facilities to support their operation due to the lack of sufficient income and reserves. Consequently, it is plausible that charities with higher indebtedness may seek to improve the charity's public performance (Boterenbrood, 2014). According to Boateng et al., (2016), the public performance could be considered by financial performance (programme spending ratio, fundraising expenses) or non-financial performance (quality of service, customer satisfaction). In light of these different reasons and the limited empirical evidence, this study formulates the third hypothesis that:

Hypothesis 3: Charity leverage is significantly associated with the extent of earnings management.

According to Pfeffer and Salancik (1978), the extent to which an organisation depends on others can be determined by the significance and concentration of resources provided. The 
fewer sources of income or the greater the dominance of few funders, the more organisations become highly dependent on, and are beholden to those providers for survival (Froelich, 1999). In a similar vein, in the UK charity context, charity operations are significantly dependent on several sources of income, such as income from charitable activities (called as charitable income), consisting of grants from central and local government for delivering public services, fee-charge from charitable services, and voluntary income comprising incoming resources generated from gifts, donations, legacies provided by the founders, patrons, supporters, the general public and business as well as grants from government and membership subscriptions, sponsorships with donation substance. Voluntary income is normally given for free from donors, supporters and grant-makers with the purpose of enhancing charitable activities performed by charities ${ }^{9}$. However, whether such dependence affects financial reporting behaviour, as per resource dependence theory, has not been extensively studied. For instance, Verbruggen and Christiaens (2012) analysed the influence of donations and governmental subsidies on earnings management practices and found no significant effect for funds donated from individuals and organisations, whilst grants from government were negatively associated to earnings management practice (Verbruggen and Christiaens, 2012). However, this relationship remains debatable because Jegers (2013) then found no significant impact of government subsidies on earnings management. Lastly, UK charities comprise of a number of charitable sectors, such as education, healthcare, environment and religion, which have different features and stakeholders, with specific levels of influence and pressure. This might consequently impact on managerial behaviour in relation to earnings management. In order to evaluate the impact of sectoral differences on earnings management practice, this study considers the inclusion of control variables to explore any sectoral impact, which is discussed further at model and variables section. 


\section{Research methodology}

\section{a. Model and variables}

This study relies on secondary data extracted from a database managed by the UK Charity Commission ${ }^{10}$. The database comprises all the financial information (the balance sheets and statement of financial activities) of more than 9,000 UK charities for a six-year period from 2007 to 2012 (with minimum income of $£ 500,000$ ). In average, the annual income of these charities accounted for nearly $90 \%$ of the annual income of all UK charities. The selection of this specific period of time also allowed for a consideration of the impact (if any) of the global financial crisis on NPOs' accounting practice.

A multivariate regression was applied to examine the relationship between earnings management and influencing factors, such as break-even target, significance of funding sources, leverage level, and the types of charitable activities. In order to test for the possible existence of earnings management practice, discretionary accruals was considered as a proxy for earnings management (Jones, 1991; Dechow et al., 1995; Verbruggen and Christiaens, 2012). According to these authors, discretionary accruals represents managerial interventions in financial reporting policies in order to change the reported financial results. Discretionary accruals is therefore used to examine the earnings management phenomenon by UK charities.

To test for the first hypothesis, an earnings frequency distribution was carried out to examine the phenomenon of reported earnings. The distribution of earnings is then analysed to identify the practice of earnings management. The presence of earnings management is indicated by an abnormal distribution of reported earnings close to zero (Leone and Van Horn, 2005; Ballantine et al., 2007; Verbruggen and Christiaens, 2012). The frequency distribution is carried out alongside a comparison of pre-managed earnings (earnings without discretionary accruals) and reported earnings, in line with the procedures by Burgstahler and Dichev (1997) as explained below. 
Burgstahler and Dichev (1997) analysed the histograms of the scaled earnings change variable with histogram interval widths of 0.0025 for the range -0.15 to +0.15 . A bell-shaped distribution with an irregularity near zero, with the distribution of slightly positive reported earnings beyond normal expectations while small losses are abnormally low relative to adjacent regions of distribution, tends to indicate the practice of earnings management (Burgstahler and Dichev, 1997; Indjejikian et al., 2014). In addition, in the context of nonprofit organizations, Leone and Van Horn (2005) also plotted histograms to identify an abnormal distribution of US hospital earnings positively around zero. Reported earnings are determined as the difference between total resource income and total resource expended. However, since UK charities are varied in terms of income and asset magnitude, the earnings ratio (earnings divided by total assets) will be used to mitigate for the differences in NPO size.

The Jones (1991) model was used to estimate discretionary accruals (DA), which are residuals from the following model (model 1). This model has been used extensively in forprofit and the non-profit sectors (DeFond and Jiambalvo, 1994; Dechow et al., 1995; Peasnell et al., 2000; Leone and Van Horn, 2005; Atieh and Hussain, 2012; Verbruggen and Christiaens, 2012).

$$
\mathrm{AC}_{\mathrm{it}} / \mathrm{TA}_{\mathrm{it}-1}=\mathrm{a}^{*} 1 / \mathrm{TA}_{\mathrm{it}-1}+\mathrm{b}_{1}^{*} \Delta \mathrm{REV}_{\mathrm{it}} / \mathrm{TAit}_{-1}+\mathrm{b}_{2}^{*} \mathrm{PPE}_{\mathrm{it}} / \mathrm{TA}_{\mathrm{it}-1}+\mathrm{e}
$$

Where, $A C_{i t}$ is charity i's total accruals calculated by the change in non-cash current assets minus the change in current liabilities from year $\mathrm{t}-1$ to year $\mathrm{t}$, minus depreciation expense for year $\mathrm{t}\left(A C_{i t}=\Delta\right.$ [Current asset - Cash] - $\triangle$ [Current liability] - Depreciation \& Amortization expenses).

$\triangle R E V_{i t}$ is the change in total income resources from year $\mathrm{t}-1$ to year $\mathrm{t}$ by charity $\mathrm{i}$.

$P P E_{i t}$ is gross depreciable assets in year t of charity $\mathrm{i}$.

$T A_{i t-1}$ is total asset year t-1 [determined by total non-current asset + (plus) total current assets]. 
Admittedly, there are several other models to estimate discretionary accruals such as the Modified Jones model (Dechow et al. 1995), the Dechow and Dichev approach (Dechow and Dichev 2002) or the Francis model (Francis et al. 2005). However, cash flow information is not compulsory for charities to disclose and the accounts receivable item appears to be insignificant in the financial statements of UK NPOs. This suggested that the application of those models may not generate more reliable results compared to the Jones (1991) model. Furthermore, the Jones (1991) model has been applied by Leone and Van Horn (2005) and Verbruggen and Christiaens (2012) in the non-profit context as well as in the corporate sector (Peasnell et al. 2000, Atieh and Hussain 2012). Furthermore, following Leone and Van Horn (2005), this study adopts the Jones (1991) model in the non-profit context, where the existence of accruals in relation to revenue and depreciation might be construed as a strategy by large NPOs (whose total income exceeds $£ 250,000$ ) to manage the bottom line (Charity Commission, 2005).

To test hypotheses 2 and 3, this paper uses the following model (model 2) which was developed from Leone and Van Horn (2005) and Verbruggen and Christiaens (2012).

$$
\begin{array}{r}
\mathrm{DA}_{i t}=\mathbf{a}_{0}+\mathbf{a}_{1} \mathrm{EBDA}_{\mathrm{it}}+\mathbf{a}_{2} \mathrm{EARNINGS}_{\mathrm{t}-1}+\mathbf{a}_{3} \mathrm{DA}_{\mathrm{it}-1}+\mathbf{a}_{4} \mathrm{LEV}_{\mathrm{it}}+\mathbf{a}_{5} \mathrm{SEC}_{-} \text {factor }+ \\
\mathbf{a}_{6} \mathrm{CHAR}_{-} \mathrm{INC}_{\mathrm{it}}+\mathbf{a}_{7} \mathrm{VOL}_{-} \mathrm{INC}_{\mathrm{it}}++\mathbf{a}_{8} \mathrm{Size}_{\mathrm{it}}+\mathbf{e}
\end{array}
$$

Whereby: $D A$ is discretionary accruals; $E B D A$ is earnings before discretionary accrual; EARNINGS is net income of previous year; $L E V$ is leverage determined by total short-term and long-term liabilities divided by previous year total assets; SEC factor is a dummy variable presenting sectoral factors; CHAR_INC is a ratio of charitable income over total income; VOL_INC is a ratio of voluntary income over total income; and Size is natural logarithm of total assets of charity.

The purpose of this model is to inspect the impact of several factors on earnings management practice, and these factors include the results for the current year (earnings 
before discretionary accruals), the level of credit and borrowings (leverage). This paper also considers several control variables, including the significance of the two main sources of income, charity size and the different sectors of non-profit activity. The relationship between these factors and discretionary accruals seeks to proxy for the motivations with regards to earnings management (Leone and Van Horn, 2005; Verbruggen and Christiaens, 2012).

\section{b. Data and sampling}

The data for this paper is directly sourced from the Charity Commission since charities have to file their accounts with the regulator ${ }^{11}$. The database provided by the Charity Commission covers approximately $84 \%$ of charity total income in England \& Wales, and we focus on financial information presented on the statement of financial activities and the balance sheet for the period 2008-2012. The sampling approach was based on the following: (i) all charities with income greater than $£ 10 \mathrm{~m}$ (835 charities); and (ii) $10 \%$ of charities with income from $£ 0.5 \mathrm{~m}$ to $£ 10 \mathrm{~m}$ (579 charities) randomly identified on the basis of a 95 percent confidence level (Saunders et al., 2012); This resulted in a final figure of 1,414 charities or 7,070 observations on a panel data basis. The combined income of the selected sample represents about 55\% of the reported income of all charities in England and Wales for 2012.

The reason for selecting charities by size is supported by previous work suggesting that larger firms are more likely to be involved in earnings management (Barton and Simko, 2002; Nelson et al., 2002) because of their higher levels of accounting sophistication and greater bargaining power. In the context of non-profit organisations, Jegers (2013) suggests that organisational size and level of earnings manipulation are positively associated. In addition, although only $10 \%$ of smaller charities are selected, the observations account for $38 \%$ of the total selected sample. Finally, charities are classified into 11 sectors based on the International Classification of Non-Profit Organisations, which was designed by the US 
Centre for Civil Society Studies at Johns Hopkins University and has been adopted by the National Council for Voluntary Organisations for UK charity classification.

\section{Empirical results and analysis}

\section{a. Descriptive statistics}

The descriptive statistics for the five-year pooled data from 2008 to 2012 are summarized in table 1 . The mean total assets and mean total income of the charities were $£ 57.032$ million and $£ 20.719$ million respectively. It is notable that mean leverage accounted for nearly $30 \%$, while charitable and voluntary income were on average the two main sources of income for UK charities, accounting respectively for approximately $58 \%$ and $26 \%$ of total income. This reflects the significant dependence on, and financial support from, a range of external stakeholders (sponsors, donors and creditors). The dependence on these two main sources of income was generally stable over the period from 2008 to 2012 . The charity sector does not seen to have been affected by the global financial crisis. Furthermore, the results showed a mean surplus for 2008 to 2012, while the mean percentage of earnings over total assets was approximately $2 \%$.

\section{[Table 1 about here]}

Table 2 provides a breakdown of the descriptive statistics by sector. There is a notable variation in relation to total assets and total income among those groups, representing a difference in size amongst selected organizations and sectors. Particularly, group 7 (Law, Advocacy and Politics) is the smallest sector with the lowest mean of total assets ( $£ 8.3$ million) and smallest mean of total income (£10million), while group 8 (Philanthropic Intermediaries and Voluntarism Promotion) is the largest sector with the mean of total assets (£191million) (approximately 34 times that of group 7). Charities involved in international activities (group 9 - International) have the highest mean income, of which voluntary income is a significant source (accounting for more than 63\%). Theoretically, in accordance with stakeholder theory 
and resource dependence theory, organisations may behave differently when there is a change in external environments related to disparities among stakeholders and variance of expectations. Therefore, it is noted that there are considerable differences in terms of the asset size, income and the main components of income between the different charitable sectors which might in turn have an effect on EM practices within particular sectors.

[Table 2 about here]

\section{b. Hypothesis 1- Earnings distribution analysis}

This paper first analyses the earnings frequency distribution by plotting histograms of reported earnings (which have been scaled by total assets to eliminate the variance in charity size). To make these comparable to pre-managed earnings, which are calculated by deducting discretionary accruals from reported earnings, the data for the distributional analysis is conducted for four years from 2009 to 2012. Consistent with the Jones (1991) model of using lagged total assets to determine discretionary accrual, our variables of reported earnings and pre-managed earnings also use lagged total assets. This leads to a reduction of one year data (from five years to four years). However, the number of observations $(5,656)$ remains sufficient to understand the reported earnings behaviour of UK charities (Jobome, 2006).

The reported earnings frequency distribution of 5,656 charity-years from 2009 to 2012, before and after applying discretionary accruals is illustrated in figure 1. Overall, the result shows that reported earnings have a slight positive mean value of 0.0526 . In particular, there are more than 3,500 observations reporting small surpluses (around 0.18), while there are slightly fewer than 2,000 observations with very small deficits (approximately -0.22 ). The results are consistent with Leone and Van Horn (2005) and Jegers (2013) in that large numbers of non-profits with earnings are distributed around zero (e.g. the mean of US hospital operating income and Belgian NPO earnings were $2.4 \%$ and $2.6 \%$ respectively), and more of the reported earnings are on the positive side than on the negative side. 
[Figure 1 about here]

Alongside a frequency distribution analysis (figure 1), we also conduct another frequency distribution analysis of reported earnings of UK charities in the period from 20082012. Our study first shows that about $39 \%$ of charities reported earnings between $-£ 250,000$ and $£ 250,000$ in the period. This interval is similar to the figure of charities' reported earnings (divided by total assets) i.e. between $-2.5 \%$ to $2.5 \%$. In this study, we consider an interval of reported earnings between $-£ 250,000$ and $£ 250,000$ as close to zero. The rationale of this assumption is initiated by the findings from prior studies as Verbruggen and Christiaens (2012) found that Belgian NPOs' earnings (mean value) were found to be reported around 2.4\% while US hospital earnings (mean value) were around 2.6\% (Leone and Van Horn, 2005).

A comparison between the frequency distributions of post-managed and pre-managed earnings reveals that the means are not significantly different (at the 5\% level). However, the number of observations with deficits is lower than the number of those with pre-managed figures (approximately 1,800 vs. 2,300), and the number with reported surpluses is more than pre-managed data (around 3,600 vs. 2,800). This may imply that many charities rely on discretionary accruals to manage earnings upward to achieve a slightly positive result. Overall, this result supports hypothesis 1 , namely that a significant number of UK charities reported earnings narrowly around zero.

The rationality of this reporting behaviour can be explained as small surpluses or deficits may create a good image for charities. Particularly, this could express the competence of managers and trustees in operating charities, since on the one hand a small surplus means that charities have sufficient funds for their activities and to achieve their stated objectives, while on the other hand, if the results are slightly negative this suggests that charities have spent their budgeted allocations and may be considered to have met the requirements of 
sponsors and donors. Furthermore, the surpluses and deficits will be added to (or reduced from) the charity reserves. According to paragraph 55 of Statement of Recommended Practice 2005 (Charity Commission, 2005), and Charities and Reserves (CC19) (Charity Commission, 2010), charities are required to disclose their reserve policy, as well as consider and explain when they have an excess or a shortfall in reserves. Therefore, this may motivate charities to use the reported figures to manage their reserve levels to avoid reporting large excesses or shortfalls. A result close to zero net income may thus keep reserves at a stable level, and make it easier for charities to explain their financial situation compared to unusual increases or decreases in reserves.

Theoretically, from the perspective of stakeholders who support charities, there is an expectation that the financial support given to charities will be directed to beneficiaries (Breeze, 2010). Therefore, a charity with a large surplus may prompt questions from donors about its efficiency, as well as its capability to fully achieve its charitable objectives. This may have a negative impact on future resources. Therefore, the managing of surpluses/deficits may be a strategy to mitigate environmental uncertainties and relationships with resource providers and to manage stakeholder perceptions more generally.

\section{c. Hypothesis 2: Earnings management towards zero level}

The summary information from table 1 shows that the charities' financial results before discretionary accruals varied from a $-16 \%$ deficit to a $31 \%$ surplus. Discretionary accruals also vary widely from -0.876 to +0.477 . This may suggest that a number of charities engage in earnings management upwards or downwards in order to achieve their intentional targets. However, in order to determine the specific behaviour of charity managers in relation to earnings management, an ordinary least squares regression is implemented. Before the regression was conducted, the regression diagnostics and Pearson correlation matrix were applied to identify issues of normality, linearity, homoscedasticity and multicollinearity (Chen 
and Zhang, 2014) ${ }^{8}$. The results show a high correlation between voluntary income (VOL_INC) and charitable income (CHAR_INC) (-0.798), because they represent the two main components of charity income. To ensure that multicollinearity will not impact on the multivariate analysis, an additional test using variance inflation factors was conducted to assess whether multicollinearity was a matter of concern (Vu, 2008; Chen and Zhang, 2014). The result of the variance inflation factors test indicated that multicollinearity was not a problem since the maximum value of variance inflation factors was 2.97 (Kennedy, 2003; Reheul et al., 2013).

In addition, an omitted variable test was also performed to determine whether there was any excluded variable which might impact on the accuracy of the regression model. Ramsey's regression specification error test was used to implement this test ( $\mathrm{Vu}, 2008)$, and the result indicated that the model may have omitted variables which could impact on the accuracy of the regression results. Consequently, this paper used panel data regression with fixed effect to eliminate the impact of omitted variables (Hsiao, 2006). The results of the regression analysis for the 4242 observations are shown in table 3 . To identify the relationship between pre-managed earnings and discretionary accruals, an additional regression was performed for the two categories of negative and positive pre-managed earnings. The division of two pre-managed earnings groups (positive and negative) can specifically reveal the reaction of charities depending on the sign of the financial results (Verbruggen and Christiaens, 2012).

\section{[Table 3 is about here]}

The relationship between discretionary accruals and earnings before discretionary accruals was negative for the whole sample, and also for the case of negative and positive premanaged earnings. In accordance with previous findings and conclusions about the negative relationship between discretionary accruals and earnings before discretionary accruals (Leone 
and Van Horn, 2005; Verbruggen and Christiaens, 2012), charities appear to pay close attention to the disclosure of the financial bottom line. If there is a high likelihood that the financial statements will report surpluses (deficits), there appears to be an adjustment of discretionary accruals downwards (upwards) to ensure a result that is close to zero. These results support the second hypothesis that charities manage earnings upwards when premanaged earnings are negative and downwards when pre-managed earnings are positive. The coefficient for this relationship is higher when pre-managed earnings are negative in comparison with positive pre-managed earnings (-0.89 vs. -0.58$)$, implying that in years with deficit results, charities may appear to be slightly more aggressive in applying accruals to manage earnings upwards than in years with positive results.

The results of this paper are consistent with Leone and Van Horn (2005)'s results from 8,179 observations in US hospitals, which suggested that earnings before discretionary accrual are in a negative relation with discretionary accruals, leading the reported earnings (the sum of earnings before discretionary accrual and discretionary accruals) to be closed to zero. This means that discretionary accruals were applied to adjust earnings towards zero depending on the positive or negative pre-managed earnings. These results are also compatible with Verbruggen and Christiaens (2012) in the context of Belgian non-profit organisations. These authors also found that Belgian NPOs exercised discretionary accruals to drive the bottom line item (earnings) in favour of zero reporting. The coefficients of EBDA (earnings before discretionary accruals) are negatively related to discretionary accruals in the case of both negative and positive EBDA, and this value is higher in the case of negative EBDA. The previous papers found that non-profit organisations are engaged in earnings management by managing earnings toward zero, and this finding can thus be extended to the wider constituency of UK charities. This may indicate a systemic managerial concern with the bottom-line result and the underlying message and image it might convey to external 
stakeholders, particularly sponsors, donors, beneficiaries and regulators. These results chime with instrumental stakeholder theory in that it suggests that charities may be behave in a specific manner (managing the bottom-line items) in order to satisfy particular stakeholders, such as sponsors, donors and regulators. Also, this practice can be explained by motivations to retain resources for operation and minimise scrutiny or intervention by regulatory bodies, even in the presence of accounting and governance regulation. A more detailed analysis is presented in relation to the different sectors in a subsequent section.

The results from this study appear to be consistent with prior findings indicating that NPOs might re-allocate expenditure (Khumawala et al., 2005; Jones and Roberts, 2006; Krishnan et al., 2006; Keating et al., 2008), manage specific expenditure items (for example, actuarial assumption and depreciation) (Pellicer et al., 2014), manage discretionary accruals (Leone and Van Horn, 2005; Verbruggen and Christiaens, 2012) or even smooth their income (Boterenbrood, 2014). Moreover, previous year earnings and past discretionary accruals also have an effect on discretionary accruals in the current year.

\section{d. Hypothesis 3: Leverage and earnings management}

The statistical analysis in table 3 suggests that leverage has a negative relationship with discretionary accruals. The results are significant for both positive and negative unmanaged earnings. This implies that charities with an increasing level of leverage consider managing earnings downwards in cases of operational surpluses, and when unmanaged earnings are negative, charities appear to manage deficits upwards. The reaction of charities in the presence of leverage not only supports Hypothesis 3, but also lends credence to the second hypothesis in that targeting zero earnings is an intention of charities. Hence, charities again show an aim of managing earnings toward zero, but one that is more robust in the presence of higher financial obligations. In this respect, Hypothesis 3 is supported. 
In order to test the relationship between leverage and earnings management, another analysis was conducted using the absolute value of discretionary accruals as the dependent variable (Davidson et al., 2005; Baxter and Cotter, 2009; Chen and Zhang, 2014). The detailed results in table 4 show a significantly positive association between the absolute value of discretionary accruals and leverage. This indicates that the higher the charity leverage, the more it uses discretionary accruals to manage financial performance to a favourable level. This finding clarifies the mixed findings from prior studies with regard to the relationship between leverage and earnings management (Verbruggen and Christiaens, 2012; Jegers, 2013), and partly supports the US-based finding by Vermeer et al. (2014) that managers of NPOs with higher leverage appear to manage income upwards.

\section{e. Impact of other factors on earnings management}

In order to assess the impact of other factors on earnings management of UK charities, this study consider several factors including sectoral differences, different types of funding, charity size as well as the impact of the global financial crisis.

First, a regression analysis on a sectoral basis was implemented to identify indications of different EM behaviour on a sectoral basis, and the results are reported in table 5 below.

[Table 5 is about here]

The results reveal that earnings before discretionary accruals are negatively associated with discretionary accrual for different sectors. These results are robust for hypotheses 1 and 2 in that charities prefer to report earnings around zero, and discretionary accruals have been applied in order to manage earnings to this favourable level. Moreover, in order to distinguish the differences of managing discretionary accruals to adjust reported earnings amongst different sectors, an alternative regression (of model 2) using dummy variables representing eleven sectors and their interaction with earnings before discretionary accruals is implemented. 
However, the results are not statistically significant and no decisive conclusion can be reached on sectoral differences with regard to earnings management.

In addition, leverage has a negative association with earnings management for all groups of charities; the result is consistent with the findings in supporting hypothesis 3 above. In order to examine the differences in impact of leverage on earnings management among these groups, an additional regression using the absolute value of discretionary accruals as dependent variable is conducted. The results suggest that except for group 7 (Law, advocacy and politics) and group 11 (Business and professional associations, unions), the results showed a significantly positive association between leverage and absolute value of discretionary accruals among the other groups. This implies that leverage may not be a factor influencing earnings management behaviour in all sectors.

In respect of other control variables, the results from Table 3 indicate that organizational size (measured by total assets) is negatively and significantly associated with discretionary accruals, and this relationship is similar to the specific case of pre-managed surpluses, but not for charities reporting pre-managed deficits. In order to confirm this relationship, an alternative test of the absolute value of discretionary accruals was conducted as suggested by prior studies (Davidson et al., 2005; Baxter and Cotter, 2009; Chen and Zhang, 2014). The results (in table 4) show a negative association between size and absolute value of discretionary accruals. This result suggests that larger charities are less likely to be involved in earnings management and may proxy for the possibility that a higher level of professionalism, reputational awareness and governance (e.g. external trustee members) is present in such charities; thereby curbing the potential for higher levels of earnings management.

Finally this study considers how the global financial crisis impacts on earnings management by UK charities by splitting the data into two periods, period 1 (2008-2009) and 
period 2 (2010-2012), to explore for any differences in the practice of earnings management by UK charities. However, the results did not suggest any significant difference in earnings management practice between two periods.

\section{f. Sensitivity analysis and robustness tests}

In order to ensure the validity of the empirical results determined from the various regression models, we conducted several sensitivity analyses and robustness tests, which included applying the two-stage least square (2SLS) method to minimise the impact of endogeneity, changing the independent variables measuring the source of income, and implementing an additional test of specific accrual (depreciation) rather than relying on overall discretionary accruals. The 2 SLS regression is based on the assumption of a potential endogenous relationship between earnings before discretionary accruals and income growth and consistently displays that two variables: EBDA and LEV are negatively associated with dependent variable: discretionary accruals (table 6).

In addition, it was suggested by Leone and Van Horn (2005) that there may be a mechanical correlation between DA and EBDA from model 2. This study therefore proposes a new proxy for EBDA (namely NEW_EBDA $A_{i t}$ ) which is equal to 1 if earnings before the discretionary accrual of charity $\mathrm{i}$ in period $\mathrm{t}$ scaled by Total Assets in period $\mathrm{t}-1$ is greater than zero, and zero otherwise. The results also show a negative association between discretionary accruals and NEW_EBDA, as well as a negative relationship between leverage and discretionary accruals. While the significance of different income sources shows the same results as the main tests, size is not significantly related to EM. Nonetheless, these results once again show robust support for the second and third hypotheses.

Lastly, this study considers the specific case of 'abnormal depreciation' as a specific accrual to examine whether charities use depreciation as a tool for earnings management. Recently, Pellicer et al. (2014) conducted a study in UK public sector bodies and suggested 
that depreciation is the main method by which local government entities manage accounting numbers. These findings may be considered in the context of UK charities since depreciation is a part of total resources expended. Abnormal depreciation is determined based on the assumption that the proportion of depreciation over gross property, plant and equipment is constant. In consequence, the over- or under-depreciated amount represents an abnormal depreciation. This figure is used to test the relationship between unexpected depreciation and earnings before unexpected depreciation; similar to discretionary accrual, the charities may over- or under-record depreciation for the purpose of managing earnings downward or upward. The results are consistent with and provide support for the main results from model 2. Depreciation thus appears to be one of the accounting tools charities use to adjust outgoing resources.

\section{Discussion and conclusion}

This paper sought to investigate whether UK charities engage in earnings management practices, and if so, what are the key organisational determinants influencing the extent of earnings management practices. By relying on stakeholder theory and resource dependence theory, mainstream measures of earnings management (distribution of reported earnings, discretionary accruals) and a relatively large data set from 1,414 charities over a five-year period, this study finds clear evidence that the reported bottom lines of UK charities are: (i) distributed narrowly around the zero level, but with an attention to display positive (surplus) rather than negative (deficit) results; and (ii) subject to discretionary accrual tactics of an upwards or downwards nature in order to manage earnings closer to zero level. Furthermore, the extent of discretionary accruals is found to fluctuate on the basis of leverage, organizational size and type of activity (sector). This is the first UK study which considers a relatively large and diversified sample of charities and as such provides evidence of a systemic behaviour in the reporting of the accounting bottom line. 
The findings are consistent with prior research claiming that non-profit organisations have various incentives to manage accounting figures by different techniques such as misclassifying functional expenditures to improve programme ratio and/or lower fundraising costs and lessen administrative expenses (Yetman, 2001; Jones and Roberts, 2006; Krishnan et al., 2006; Keating et al., 2008; Tinkelman, 2009; Yetman and Yetman, 2012), using discretionary accruals to manage earnings towards the zero level (Leone and Van Horn, 2005; Ballantine et al., 2007; Verbruggen and Christiaens, 2012; Jegers, 2013). This paper finds that a number of UK charities reported small positive earnings (surplus) or little losses around zero (hypothesis 1). When the results show a significant surplus or considerable deficits, discretionary accrual may be applied in order to direct earnings toward zero (hypothesis 2). This level is not a statutory benchmark, but it provides a way for charity trustees to balance resources and expenditure as well as demonstrate efficiency in their operations. Moreover, this study suggests that leverage has an association with discretionary accruals (hypothesis 3 ). This finding thus posits that charities with a large amount of debt and credit obligations seem to be more likely to be involved in EM. This is a significant result in that previous NPO studies did not find support for the effect of leverage on EM behaviour. These findings were found to be robust by testing for abnormal depreciation as a specific accrual, considering the use of alternative independent variables and relying on the two-stage least square (2SLS) method.

In spite of their economic importance and valuable findings from an emerging literature, little is known about the financial reporting practices of non-profit organisations in the UK. This study attributes this to the absence of a comprehensive financial database for UK charities compared to the United States for instance. As a result, the findings and analysis of this study have key implications. First, stakeholder theory and resource dependence theory provide a very useful theoretical framework to understand the wider motivations behind 
earnings management in a non-profit context and to analyse the results thereof. In particular, the combination of an instrumental perspective on stakeholder theory and resource dependence theory can substitute for agency theory in explaining the varying behaviour of non-profit executives. For example, the target reporting of close to zero earnings in UK charities might be motivated by consideration of key stakeholders and uncertainties in accessing future resources. Second, while the UK context can be characterised as one where the regulatory framework of accounting for charities is highly developed (indeed, it has inspired reforms in other countries), the evidence reinforces the view that accrual accounting can also offer the potential for discretionary behaviour by NPOs. Whilst not a novel insight in itself, this finding will be of interest to the Charity Commission, which may help strengthen its monitoring activities by taking into account the extent of discretionary accrual practices adopted by charities. Since it carries out a regime risk-based inspections, the extent of EM may indirectly highlight concerns about internal practices and governance in such an organisation.

However, there are some limitations in terms of the data relied upon in this paper. There is insufficient information on the specific providers of income, which, if available, would have allowed for a more rigorous analysis of the impact of different stakeholders and resource providers on earnings management behaviour. Also, the empirical results from this study would be more informative if cash flow data could be collected, thereby enabling the use of other discretionary accrual metrics and models such as the Modified Jones model, the Dechow and Dichev approach or the Francis model. Nonetheless, the results provide sufficient evidence to spur the debate on the reliability of SORP-based accounting information in the UK charitable context. 


\section{Endnotes}

1. NPO is a generic term for all third sector organisations which do not distribute profits or surpluses for the benefit of members, shareholders or other financial motivated stakeholders. Most NPOs typically operate under the constraint of 'non-dividend distribution' although that many of them generate profits or surpluses. In the UK context, NPOs comprise of two types of organisational structures, (i) charities and community groups and (ii) social enterprises. However, in this study, we focus on charities as a main player of UK NPOs. (Source:

https://www.resourcecentre.org.uk/information/legal-structures-for-not-for-profit-organisations/). 2. For example, in August 2012 a charity named 'Fund for the Blind and Partially Sighted' was convicted of theft and misleading information to the Commission under the Charities Act, and in another case AA Hamilton College Limited, a higher education college, was found to employ poor financial controls and unauthorised benefits due to the fact that two trustees were employed as staff members (Source: Charity Commission: Annual reports and Account 2012-13, p.11).

3. http://apps.charitycommission.gov.uk

4. According to 'What is the sector's contribution to the economy?' published by NCVO at http://data.ncvo.org.uk/a/almanac14/what-is-the-sectors-contribution-to-the-economy/

5. SORP for charity accounting was initially prepared and issued by the Accounting Standard Committee (ASC) in 1988 with a 'Statement of Recommended Practice No 2 (Accounting by Charities)' - SORP 2.

6. http://data.ncvo.org.uk/a/almanac12/what-impact-did-the-recession-have-upon-the-voluntary-sector/ 7. http://www.theguardian.com/society/2012/dec/09/one-in-six-charities-close

8. 'Earnings' is a general term indicating the operational result of charities, according to SORP 2005, defined as 'Net incoming/outgoing resources before transfers'. It is determined by total incoming resources minus total resources expended.

9. Other sources of charity income include investment income and other incoming resources.

10. The authors sought permission from the UK Charity Commission to use the database for research purposes. This database is now publicly available at http://data.charitycommission.gov.uk/default.aspx 11. The data collected from the UK Charity Commission with a permission to be used for research purpose.

12. Because of the extreme kurtosis and significant skewness problems, a winsorizing of the two variables (EBDAit and EARNINGSit-1) at 5\% was performed to resolve these issues. 


\section{References}

Atieh, A. and Hussain, S. (2012). Do UK firms manage earnings to meet dividend thresholds? Accounting and Business Research, 42 (1), 77-94.

Ballantine, J., Forker, J. and Greenwood, M. (2007). Earnings management in English NHS hospital Trusts. Financial Accountability \& Management, 23 (4), 421-440.

Barton, J. and Simko, P.J. (2002). The balance sheet as an earnings management constraint. The Accounting Review, 77 (4), 1.

Baxter, P. and Cotter, J. (2009). Audit committees and earnings quality. Accounting \& Finance, 49 (2), 267-290.

Beattie, V. and Jetty, J. (2009). Disclosure practices and policies of UK charities. London: Certified Accountants Educational Trust. Retrieved from: http://www.accaglobal.com

Bergstresser, D. and Philippon, T. (2006). CEO incentives and earnings management. Journal of Financial Economics, 80 (3), 511-529.

Boateng, A., Akamavi, R.K. and Ndoro, G. (2016), Measuring performance of non-profit organisations: Evidence from large charities. Business Ethics: A European Review, 25 (1), 59-74.

Boterenbrood, R. (2014). Income smoothing by Dutch hospitals. Journal of Accounting and Public Policy, 33 (5), 510-524.

Breeze, B. (2010). How donors choose charities. London: Centre for Charitable Giving and Philanthropy.

Buchheit, S. and Parsons, L.M. (2006). An experimental investigation of accounting information's influence on the individual giving process. Journal of Accounting and Public Policy, 25 (2006), 666-686.

Burgstahler, D. and Dichev, I. (1997). Earnings management to avoid earnings decreases and losses. Journal of Accounting and Economics, 24 (1), 99-126. 
Charity Commission (2005). Accounting and reporting by charities: Statements of recommended practice. London: Charity Commission.

Charity Commission (2009). RS22: Charities' awareness, understanding and attitudes towards public benefit requirement. London: Charity Commission.

Charity Commission (2010). CC19: Charities and reserves. London: Charity Commission.

Charity Commission (2013). Charity reporting and accounting: The essentials. London: Charity Commission.

Chen, J.J. and Zhang, H. (2014). The impact of the corporate governance code on earnings management - Evidence from Chinese listed companies. European Financial Management, $20(3), 596-632$.

Connolly, C. and Hyndman, N. (2001). A comparative study on the impact of revised SORP 2 on British and Irish charities. Financial Accountability \& Management, 17 (1), 73-97.

Davidson, R., Goodwin-Stewart, J. and Kent, P. (2005). Internal governance structures and earnings management. Accounting \& Finance, 45 (2), 241-267.

Dechow, P., Sloan, R. and Sweeney, A. (1995). Detecting earnings management. The Accounting Review, 70, 193-225.

Defond, M.L. and Jiambalvo, J. (1994). Debt covenant violation and manipulation of accruals. Journal of Accounting and Economics, 17 (1-2), 145-176.

Dodd, L. (2014) Charity under pressure to break even. The Tablet, 8th February.

Dolnicar, S., Irvine, H.J. and Lazarevski, K. (2008). Mission or money? Competitive challenges facing public sector nonprofit organisations in an institutionalised environment. International Journal of Nonprofit and Voluntary Sector Marketing, 13, 107-117.

Donaldson, T. and Preston, L.E. (1995). The stakeholder theory of the corporation: Concepts, evidence, and implications. Academy of Management Review, 20 (1), 65-91. 
Eldenburg, L.G., Gunny, K.A., Hee, K.W. and Soderstrom, N. (2011). Earnings management using real activities: Evidence from nonprofit hospitals. The Accounting Review, 86 (5), 1605-1630.

Ferreira, A., Carvalho, J. and Pinho, F. (2013). Earnings management around zero: A motivation to local politician signalling competence. Public Management Review, 15 (5), 657-686.

Friedlan, J.M. (1994). Accounting choices of issuers of initial public offerings. Contemporary Accounting Research, 11 (1), 1-31.

Froelich, K.A. (1999). Diversification of revenue strategies: Evolving resource dependence in nonprofit organisations. Nonprofit and Voluntary Sector Quarterly, 28 (3), 246-268.

Garven, S.A., Hofmann, M.A. and Mcswain, D.N. (2016). Playing the numbers game: Program ratio management in nonprofit organisations. Nonprofit Management and Leadership, 26 (4), 401-416.

Healy, P.M. (1985). The effect of bonus schemes on accounting decisions. Journal of Accounting and Economics, 7 (1/2/3), 85-107.

Healy, P.M. and Wahlen, J.M. (1999). A review of the earnings management literature and its implications for standard setting. Accounting Horizons, 13 (4), 365-383.

Hofmann, M.A. (2007). Tax-motivated expense shifting by tax-exempt associations. The Journal of the American Taxation Association, 29 (1), 43-60.

Hofmann, M.A. and Mcswain, D. (2013). Financial disclosure management in the nonprofit sector: A framework for past and future research. Journal of Accounting Literature, 32 (1), 61-87.

Hsiao, C. (2006). Panel data analysis: Advantages and challenges. IEPR Working Paper No. 06.49. 
Hyndman, N. and Mcmahon, D. (2010). The evolution of the UK charity Statement of Recommended Practice: The influence of key stakeholders. European Management Journal, 28 (6), 455-466.

Indjejikian, R.J., Matejka, M., Merchant, K.A. and Van Der Stede, W.A. (2014). Earnings Targets and Annual Bonus Incentives. The Accounting Review, 89 (4), 1227-1258.

Jaggi, B. and Picheng, L. (2002). Earnings management response to debt covenant violations and debt restructuring. Journal of Accounting, Auditing and Finance, 17 (4), 295-324.

James, S.B. (2014) Charity Commission concerned over net liabilities of many large charities. Third sector. Available from: http://www.thirdsector.co.uk [Accessed 17 August 2014].

Jegers, M. (2013). Do nonprofit organisations manage earnings? An empirical study. VOLUNTAS: International Journal of Voluntary and Nonprofit Organisations, 24 (4), $953-$ 968.

Jiang, J., Petroni, K.R. and Wang, I.Y. (2010). CFOs and CEOs: Who have the most influence on earnings management? Journal of Financial Economics, 96 (3), 513-526.

Jobome, G.O. (2006). Public funding, governance and passthrough efficiency in large UK charities. Corporate Governance: An International Review, 14 (1), 43-59.

Jones, C.L. and Roberts, A.A. (2006). Management of financial information in charitable organisations: The case of joint-cost allocations. The Accounting Review, 81 (1), 159-178.

Jones, J.J. (1991). Earnings management during import relief investigations. Journal of Accounting Research, 29 (2), 193-228.

Keating, E.K., Parsons, L.M. and Roberts, A.A. (2008). Misreporting fundraising: How do nonprofit organisations account for telemarketing campaigns? The Accounting Review, 83 (2), 417-446.

Kennedy, P.E. (2003). A guide to econometrics, 5th ed. Boston, MA: MIT Press. 
Khumawala, S.B., Parsons, L.M. and Gordon, T.P. (2005). Tracks- Assessing the quality of not-for-profit efficiency ratios: Do donors use joint cost allocation disclosures? Journal of Accounting, Auditing \& Finance, 20 (3), 287.

Krishnan, R., Yetman, M.H. and Yetman, R.J. (2006). Expense misreporting in nonprofit organisations. The Accounting Review, 81 (2), 399-420.

Leone, A.J. and Van Horn, R.L. (2005). How do nonprofit hospitals manage earnings? Journal of Health Economics, 24 (4), 815-837.

Miloud, T. (2014). Earnings management and initial public offerings: An empirical analysis. Journal of Applied Business Research, 30 (1), 117-134.

National Council for Voluntary Organisations (2012). How are public sector spending cuts affecting the voluntary sector? . Ncvo. Retrieved from: https://data.ncvo.org.uk/a/almanac12/how-are-public-sector-spending-cuts-affecting-thevoluntary-sector/.

Nelson, M.W., Elliott, J.A. and Tarpley, R.L. (2002). Evidence from auditors about managers' and auditors' earnings management decisions. The Accounting Review, 77, 175-202.

Newton, A.N. (2015). Executive compensation, organizational performance, and governance quality in the absence of owners. Journal of Corporate Finance, 30, 195-222.

Omer, T.C. and Yetman, R.J. (2003). Near zero taxable income reporting by nonprofit organisations. The Journal of the American Taxation Association, 25 (2), 19-34.

Omer, T.C. and Yetman, R.J. (2007). Tax misreporting and avoidance by nonprofit organisations. The Journal of the American Taxation Association, 29 (1), 61-86.

Peasnell, K.V., Pope, P.F. and Young, S. (2000). Detecting earnings management using crosssectional abnormal accruals models. Accounting and Business Research, 30 (4), 313-326. 
Pellicer, M.J.A., Hodges, R. and Martí, C. (2014). Earnings management in English local governments: Determining factors and instruments. Working paper-Universidad de Zaragoza and University of Birmingham.

Pfeffer, J. and Salancik, G.R. (1978). The external control of organisations: A resource dependence perspective. New York: Harper \& Row.

Reheul, A.M., Van Caneghem, T. and Verbruggen, S. (2013). Audit report lags in the Belgian non-profit sector: An empirical analysis. Accounting and Business Research, 43 (2), 138158.

Saleh, N.M. and Ahmed, K. (2005). Earnings management of distressed firms during debt renegotiation. Accounting and Business Research, 35 (1), 69-86.

Saunders, M.N.K., Lewis, P. and Thornhill, A. (2012). Research methods for business students, 6th ed. Harlow: Pearson Education Limited.

Tinkelman, D. (1999). Factors affecting the relation between donations to not-for-profit organisations and an efficiency ratio. Research in Government and Non-profit Accounting, $10,135-161$.

Tinkelman, D. (2009). Unintended consequences of expense ratio guidelines: The Avon breast cancer walks. Journal of Accounting and Public Policy, 28 (6), 485-494.

Van Puyvelde, S., Caers, R., Du Bois, C. and Jegers, M., 2012. The governance of nonprofit organizations: Integrating agency theory with stakeholder and stewardship theories. Nonprofit and voluntary sector quarterly, 41(3), pp.431-451.

Verbruggen, S. and Christiaens, J. (2012). Do non-profit organisations manage earnings toward zero profit and does governmental financing play a role? Canadian Journal of Administrative Sciences, 29 (3), 205-217. 
Vermeer, T.E., Edmonds, C.T. and Asthana, S.C. (2014). Organisational form and accounting choice: Are nonprofit or for-profit managers more aggressive? Accounting Review, 89 (5), 1867-1893.

Vu, T.B. (2008). Foreign direct investment and endogenous growth in Vietnam. Applied Economics, 40 (7-9), 1165-1173.

Walker, M. (2013). How far can we trust earnings numbers? What research tells us about earnings management. Accounting and Business Research, 43 (4), 445-481.

Wilson, M. and Shailer, G. (2007). Accounting manipulations and political costs: Tooth \& Co Ltd, 1910-1965. Accounting and Business Research, 37 (4), 247-266.

Yetman, M.H. and Yetman, R.J. (2012). The effects of governance on the accuracy of charitable expenses reported by nonprofit organisations. Contemporary Accounting Research, 29 (3), 738-767.

Yetman, M.H. and Yetman, R.J. (2013). Do donors discount low-quality accounting information? The Accounting Review, 88 (3), 1041-1067.

Yetman, R.J. (2001). Tax-motivated expense allocations by nonprofit organisations. The Accounting Review, 76 (3), 297-311. 


\section{Tables and figures}

Table 1: Descriptive statistics

\begin{tabular}{|c|c|c|c|c|c|c|}
\hline \multicolumn{2}{|l|}{ Items (in GBP) } & Mean & $\begin{array}{l}\text { Standard } \\
\text { deviation }\end{array}$ & Perc.25 & Median & Perc.75 \\
\hline \multicolumn{2}{|l|}{ Total Asset } & $57,032,080$ & $433,405,636$ & $3,206,022$ & $12,256,266$ & $35,462,014$ \\
\hline \multicolumn{2}{|l|}{ Total Liability } & $14,146,786$ & $82,844,491$ & 388,603 & $2,213,000$ & $7,005,074$ \\
\hline \multicolumn{2}{|l|}{ Leverage } & $29.64 \%$ & $29.72 \%$ & $8.31 \%$ & $22.10 \%$ & $42.27 \%$ \\
\hline \multicolumn{2}{|l|}{ Total Income } & $20,719,039$ & $47,244,579$ & $2,143,567$ & $10,558,425$ & $19,965,408$ \\
\hline \multicolumn{2}{|l|}{ Charitable Income } & $11,979,547$ & $31,966,269$ & 431,490 & $2,875,614$ & $13,055,562$ \\
\hline \multicolumn{2}{|c|}{ Voluntary Income } & $5,903,279$ & $24,787,801$ & 11,000 & 324,523 & $2,685,093$ \\
\hline \multicolumn{2}{|c|}{ Earnings (Surplus/Deficits) } & 546,054 & $16,562,740$ & $-54,680$ & 172,649 & 977,001 \\
\hline \multicolumn{2}{|c|}{$\begin{array}{l}\text { Charitable Income/Total } \\
\text { Income }\end{array}$} & $58.10 \%$ & $40.36 \%$ & $8.87 \%$ & $76.08 \%$ & $96.09 \%$ \\
\hline \multicolumn{2}{|c|}{$\begin{array}{l}\text { Voluntary income/Total } \\
\text { income }\end{array}$} & $26.02 \%$ & $33.92 \%$ & $0.21 \%$ & $5.32 \%$ & $50.17 \%$ \\
\hline \multicolumn{2}{|c|}{ Earnings/Total assets } & $2.2 \%$ & $44.16 \%$ & $-0.98 \%$ & $2.49 \%$ & $6.84 \%$ \\
\hline \multicolumn{7}{|c|}{$N=1414$ charities $(7,070$ observations $)$} \\
\hline \multicolumn{2}{|c|}{$\begin{array}{ll}\text { Variables } & \mathbf{N}\end{array}$} & Mean & Std. dev. & Min & Median & Max \\
\hline $\mathrm{DA}_{\mathrm{it}}$ & 4242 & 0.000000 & 0.108505 & -0.875694 & 0.003989 & 0.477413 \\
\hline $\mathrm{EBDA}_{\mathrm{it}}$ & 4242 & 0.036929 & 0.114020 & -0.161457 & 0.019982 & 0.310464 \\
\hline EARNINGS $_{\mathrm{i}, \mathrm{t}-1}$ & 4242 & 0.037679 & 0.088504 & -0.115804 & 0.024619 & 0.264029 \\
\hline $\mathrm{DA}_{\mathrm{i}, \mathrm{t}-1}$ & 4242 & 0.000000 & 0.112011 & -0.875694 & 0.006449 & 0.604326 \\
\hline $\mathrm{LEV}_{\mathrm{it}}$ & 4242 & 0.292466 & 0.286316 & 0 & 0.219712 & 4.443969 \\
\hline VOL_INC ${ }_{\mathrm{it}}$ & 4242 & 0.2614498 & 0.342187 & 0 & 0.051851 & 1 \\
\hline CHAR_INC & 4242 & 0.5841176 & 0.404393 & 0 & $\begin{array}{c}0.761319 \\
9\end{array}$ & 1 \\
\hline Size $_{i t}$ & 4242 & 16.15339 & 1.811005 & 10.58266 & 16.32477 & 23.45875 \\
\hline
\end{tabular}

$\mathrm{DA}_{\mathrm{it}}$ is the residual from the Jones model (equation 1). $\mathrm{EBDA}_{\mathrm{it}}$ is earnings before discretionary accruals $=$ Earnings $_{\mathrm{it}} /$ Total $_{\text {assets }} \mathrm{i,t-1}$ - Discretionary accruals. EARNINGS $\mathrm{i}_{\mathrm{i}, \mathrm{t}-1}$ is earnings in year $\mathrm{t}-1$ scaled by lagged total assets. $\mathrm{DA}_{\mathrm{i}, \mathrm{t}-\mathrm{1}}$ is discretionary accruals in year $\mathrm{t}-1 . \mathrm{LEV}_{\text {it }}$ is total short-term and long-term creditor in year $\mathrm{t}$ scaled by total assets in year $\mathrm{t}-1$. CHAR_INC $\mathrm{It}_{\mathrm{it}}$ is a proportion of charitable income over total income in year t. VOL_INC ${ }_{\text {it }}$ is a proportion of voluntary income over total income in year t. Size ${ }_{i t}$ is the natural logarithm of the total assets of charity $i$ in year t. The data for model 2 is limited to 4242 observations (1414 charities across 3 years) as $\mathrm{DA}_{\mathrm{it}}$ is available for 2010 to 2012 and $\mathrm{DA}_{\mathrm{i}, \mathrm{t}-\mathrm{i}}$ is available for 2009 to 2011 (lagged assets). 
Table 2: Descriptive statistics per charity sector (2008 to 2012)

\begin{tabular}{|c|c|c|c|c|c|c|c|c|c|c|c|c|}
\hline Items & Statistics & Group 1 & Group 2 & Group 3 & Group 4 & Group 5 & Group 6 & Group 7 & Group 8 & Group 9 & Group 10 & Group 11 \\
\hline & $\mathbf{N}$ & 655 & 1705 & 620 & 1055 & 320 & 850 & 200 & 450 & 270 & 700 & 245 \\
\hline \multirow[t]{3}{*}{ Total Asset (£’000) } & Mean & 24,100 & 76,800 & 34,200 & 29,600 & 41,900 & 58,000 & 8,315 & 191,000 & 29,500 & 56,000 & 26,100 \\
\hline & Std. Deviation & 55,100 & 819,000 & 80,800 & 68,200 & 136,000 & 116,000 & 20,700 & 559,000 & 68,900 & 74,900 & 37,800 \\
\hline & Median & 5,674 & 16,900 & 8,732 & 5,695 & 8,762 & 16,000 & 762 & 20,600 & 11,100 & 27,900 & 13,600 \\
\hline \multirow{3}{*}{$\begin{array}{l}\text { Total Liability } \\
\left(£^{\prime} 000\right)\end{array}$} & Mean & 7,565 & 16,200 & 11,400 & 4,911 & 5,694 & 38,600 & 2,074 & 27,600 & 8,997 & 5,257 & 6,748 \\
\hline & Std. Deviation & 33,200 & 137,000 & 45,300 & 10,500 & 15,600 & 81,300 & 5,411 & 129,000 & 30,200 & 14,300 & 10,400 \\
\hline & Median & 1,537 & 4,367 & 967 & 1,161 & 910 & 4,545 & 217 & 1,595 & 2,669 & 1,593 & 3,496 \\
\hline \multirow{3}{*}{ Leverage $(\%)$} & Mean & $37 \%$ & $32 \%$ & $20 \%$ & $27 \%$ & $22 \%$ & $50 \%$ & $29 \%$ & $22 \%$ & $30 \%$ & $13 \%$ & $31 \%$ \\
\hline & Std. Deviation & $31 \%$ & $22 \%$ & $20 \%$ & $25 \%$ & $28 \%$ & $45 \%$ & $19 \%$ & $26 \%$ & $24 \%$ & $17 \%$ & $43 \%$ \\
\hline & Median & $30 \%$ & $28 \%$ & $13 \%$ & $20 \%$ & $11 \%$ & $40 \%$ & $27 \%$ & $10 \%$ & $24 \%$ & $6 \%$ & $23 \%$ \\
\hline \multirow[t]{3}{*}{ Total Income (£’000) } & Mean & 17,800 & 19,100 & 24,500 & 21,400 & 22,500 & 23,000 & 10,000 & 18,900 & 52,900 & 12,700 & 16,600 \\
\hline & Std. Deviation & 54,500 & 39,500 & 65,900 & 38,800 & 55,700 & 37,400 & 18,900 & 49,900 & 104,000 & 15,300 & 18,200 \\
\hline & Median & 8,555 & 11,700 & 6,215 & 9,476 & 4,900 & 13,100 & 1,247 & 6,025 & 23,200 & 10,300 & 11,900 \\
\hline \multirow{3}{*}{$\begin{array}{l}\text { Charitable Income } \\
\left(£^{\prime} 000\right)\end{array}$} & Mean & 6,644 & 13,200 & 15,100 & 13,500 & 8,111 & 20,100 & 6,798 & 5,343 & 19,000 & 3,722 & 12,200 \\
\hline & Std. Deviation & 9,912 & 22,600 & 56,600 & 25,700 & 30,900 & 33,800 & 15,600 & 33,800 & 74,300 & 8,500 & 15,700 \\
\hline & Median & 2,549 & 10,000 & 1,601 & 2,660 & 805 & 11,600 & 895 & - & 1,174 & 704 & 9,390 \\
\hline \multirow{3}{*}{$\begin{array}{l}\text { Voluntary Income } \\
\left(£^{\prime} 000\right)\end{array}$} & Mean & 7,603 & 3,059 & 7,238 & 5,630 & 10,300 & 1,291 & 1,435 & 7,722 & 29,800 & 6,934 & 324 \\
\hline & Std. Deviation & 38,400 & 20,700 & 34,400 & 18,300 & 22,300 & 7,691 & 4,325 & 32,100 & 46,600 & 11,700 & 851 \\
\hline & Median & 546 & 116 & 1,025 & 276 & 962 & 2 & 67 & 688 & 11,100 & 3,055 & 6 \\
\hline \multirow{3}{*}{$\begin{array}{l}\text { Earnings } \\
\text { (Surplus/Deficits) } \\
\left(£^{\prime} 000\right)\end{array}$} & Mean & 761 & -409 & 971 & 637 & 889 & 778 & 425 & 2,200 & 845 & 483 & 813 \\
\hline & Std. Deviation & 4,120 & 29,600 & 6,182 & 4,639 & 4,191 & 5,841 & 1,945 & 26,200 & 7,801 & 5,315 & 3,055 \\
\hline & Median & 56 & 438 & 208 & 80 & 124 & 198 & 31 & 78 & 373 & 67 & 242 \\
\hline \multirow{3}{*}{$\begin{array}{l}\text { Charitable } \\
\text { Income/Total Income } \\
(\%)\end{array}$} & Mean & $51.57 \%$ & $78.67 \%$ & $47.60 \%$ & $64.79 \%$ & $35.39 \%$ & $81.03 \%$ & $70.49 \%$ & $21.88 \%$ & $27.91 \%$ & $22.64 \%$ & $71.20 \%$ \\
\hline & Std. Deviation & $32.35 \%$ & $32.46 \%$ & $38.69 \%$ & $38.35 \%$ & $34.49 \%$ & $30.13 \%$ & $37.34 \%$ & $37.84 \%$ & $37.24 \%$ & $29.63 \%$ & $30.96 \%$ \\
\hline & Median & $52.58 \%$ & $93.96 \%$ & $37.05 \%$ & $84.60 \%$ & $28.05 \%$ & $95.78 \%$ & $91.99 \%$ & $0.00 \%$ & $2.99 \%$ & $7.81 \%$ & $87.25 \%$ \\
\hline \multirow{3}{*}{$\begin{array}{l}\text { Voluntary } \\
\text { Income/Total Income } \\
(\%)\end{array}$} & Mean & $28.70 \%$ & $11.91 \%$ & $31.36 \%$ & $22.43 \%$ & $41.07 \%$ & $8.14 \%$ & $21.19 \%$ & $38.58 \%$ & $63.29 \%$ & $59.61 \%$ & $5.27 \%$ \\
\hline & Std. Deviation & $29.83 \%$ & $24.80 \%$ & $30.24 \%$ & $30.35 \%$ & $35.23 \%$ & $19.91 \%$ & $32.70 \%$ & $39.68 \%$ & $40.04 \%$ & $32.99 \%$ & $15.04 \%$ \\
\hline & Median & $18.28 \%$ & $1.18 \%$ & $24.94 \%$ & $5.86 \%$ & $35.86 \%$ & $0.07 \%$ & $2.24 \%$ & $21.36 \%$ & $85.90 \%$ & $70.11 \%$ & $0.17 \%$ \\
\hline
\end{tabular}

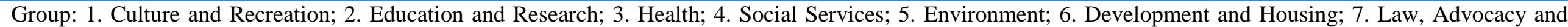

Politics; 8. Philanthropic intermediaries and voluntarism promotion; 9. International; 10. Religion; 11. Business and professional associations, unions. 
Table 3: Regression results on entire sample

\begin{tabular}{|c|c|c|c|c|c|c|c|}
\hline \multirow{2}{*}{$\begin{array}{l}\text { Regression } \\
\text { DA } \\
\text { Variables }\end{array}$} & \multicolumn{3}{|c|}{ All EBDA } & \multicolumn{2}{|c|}{ Positive EBDA } & \multicolumn{2}{|c|}{ Negative EBDA } \\
\hline & Exp.n & Coef. & T-value & Coef. & T-value & Coef. & T-value \\
\hline INTERCEPT & & 1.01 & 3.24 & 1.28 & 8.55 & -0.03 & -0.12 \\
\hline $\mathrm{EBDA}_{\mathrm{it}}$ & - & -0.64 & $-23.63 * * *$ & -0.58 & $-20.76 * * *$ & -0.89 & $-12.96^{* * *}$ \\
\hline EARNINGS $_{\mathrm{i}, \mathrm{t}-1}$ & & -0.16 & $-5.33 * * *$ & -0.11 & $-3.71 * * *$ & -0.06 & -1.59 \\
\hline $\mathrm{DA}_{\mathrm{i}, \mathrm{t}-1}$ & & -0.24 & $-11.87 * * *$ & -0.22 & $-11.49 * * *$ & -0.15 & $-7.15 * * *$ \\
\hline $\mathrm{LEV}_{\text {it }}$ & - & -0.25 & $-4.42 * * *$ & -0.17 & $-9.93 * * *$ & -0.37 & $-10.22 * * *$ \\
\hline VOL_INC & - & 0.07 & $2.25^{* * *}$ & 0.06 & $2.36^{* *}$ & 0.08 & $1.98 * *$ \\
\hline CHAR_INC ${ }_{\text {it }}$ & - & 0.003 & 0.17 & -0.01 & -0.68 & 0.024 & 0.86 \\
\hline Size & & -0.06 & $-3.03 * * *$ & -0.07 & $-7.05 * * *$ & 0.006 & 0.36 \\
\hline Sector 1 & & 0.0049 & 0.57 & & & & \\
\hline Sector 2 & & 0.0052 & 0.66 & & & & \\
\hline Sector 3 & & -0.0060 & -0.69 & & & & \\
\hline Sector 4 & & -0.0010 & -0.12 & & & & \\
\hline Sector 5 & & -0.0057 & -0.58 & & & & \\
\hline Sector 6 & & 0.0083 & 0.99 & & & & \\
\hline Sector 7 & & -0.0004 & -0.04 & & & & \\
\hline Sector 8 & & -0.0109 & -1.18 & & & & \\
\hline Sector 9 & & -0.0017 & -0.17 & & & & \\
\hline Sector 10 & & -0.0151 & -1.70 & & & & \\
\hline $\mathrm{N}$ & & 4242 & & 2551 & & 1691 & \\
\hline $\mathrm{R}$ square & & 0.1312 & & 0.0249 & & 0.0215 & \\
\hline F-value & & 139.46 & & 115.74 & & 46.06 & \\
\hline Prob $>\mathrm{F}$ & & 0.0000 & & 0.0000 & & 0.0000 & \\
\hline VIF maximum & & 2.97 & & 2.76 & & 2.73 & \\
\hline
\end{tabular}

$* * *, * *$ : Significance at $1 \%$ and $5 \%$ level.

$\mathrm{DA}_{\mathrm{it}}$ is discretionary accruals in year $\mathrm{t}$. EBDA $\mathrm{it}_{\mathrm{it}}$ is earnings before discretionary accruals. EARNINGS $\mathrm{i}_{\mathrm{t}, \mathrm{l}}$ is earnings in year $\mathrm{t}-1$ scaled by lagged total assets. $\mathrm{DA}_{\mathrm{i}, \mathrm{t}-1}$ is discretionary accruals in year $\mathrm{t}-1$. $\mathrm{LEV}_{\mathrm{it}}$ is total short-term and longterm creditor in year $\mathrm{t}$ scaled by total assets in year $\mathrm{t}-1$. CHAR_INC $\mathrm{it}_{\mathrm{t}}$ is proportion of charitable income over total income in year t. VOL_INC $\mathrm{It}_{\mathrm{it}}$ is proportion of voluntary income over total income in year $\mathrm{t}$. Size $\mathrm{it}_{\mathrm{it}}$ is the natural logarithm of total assets of charity $i$ in year t. Sector is a dummy variable. 
Table 4: Regression results with dependent variable as the absolute value of discretionary accruals

\begin{tabular}{llc}
\hline Variables & Coef. & t \\
\hline EBDA $_{\text {it }}$ & 0.094 & $8.07^{* *}$ \\
EARNING $_{\text {i,t-1 }}$ & 0.045 & $2.79^{* *}$ \\
DA $_{\text {i,t-1 }}$ & 0.016 & 1.51 \\
VOL_INC $_{\text {it }}$ & -0.010 & -0.69 \\
CHAR_INC $_{\text {it }}$ & -0.010 & -0.8 \\
LEV $_{\text {it }}$ & 0.048 & $4.44^{* *}$ \\
Size & -0.024 & $-3.71^{* *}$ \\
Constant & 0.443 & $4.27^{* *}$ \\
N & \multicolumn{3}{c}{4242} \\
F(7,2821) & \multicolumn{2}{c}{19.12} \\
\hline Prob > F & \multicolumn{2}{c}{0.0000} \\
R square & \multicolumn{2}{c}{0.1447} \\
\hline
\end{tabular}

**, *: Significance at $1 \%$ and $5 \%$ level.

Dependent variable is absolute value of discretionary accruals in year t. $\mathrm{EBDA}_{\mathrm{it}}$ is earnings before discretionary accruals. EARNINGS $\mathrm{S}_{\mathrm{i}, \mathrm{t}-1}$ is earnings in year $\mathrm{t}-1$ scaled by lagged total assets. $\mathrm{DA}_{\mathrm{i}, \mathrm{t}-1}$ is discretionary accruals in year $\mathrm{t}-1 . \mathrm{LEV}_{\mathrm{it}}$ is total short-term and long-term creditor in year t scaled by total assets in year t-1. CHAR_INC $\mathrm{it}_{\mathrm{it}}$ is proportion of charitable income over total income in year $\mathrm{t}$. VOL_INC $\mathrm{It}_{\mathrm{it}}$ is proportion of voluntary income over total income in year $\mathrm{t}$. Size $\mathrm{it}_{\mathrm{t}}$ is the natural logarithm of total assets of charity i in year $\mathrm{t}$. 
Table 5: Regression results by sector

\begin{tabular}{|c|c|c|c|c|c|c|c|c|c|c|c|}
\hline Group & 1 & 2 & 3 & 4 & 5 & 6 & 7 & 8 & 9 & 10 & 11 \\
\hline EBDA $_{i t}$ & $-0.68 * * *$ & $-0.43 * * *$ & $-0.58 * * *$ & $-0.64 * * *$ & $-0.73 * * *$ & $-0.64 * * *$ & $-1.13 * * *$ & $-0.62 * * *$ & $-0.89 * * *$ & $-0.30 * * *$ & $-0.71 * * *$ \\
\hline EARNINGS $_{\mathrm{i}, \mathrm{t}-1}$ & $-0.23 * * *$ & $-0.15 * * *$ & $-0.11 * *$ & -0.03 & -0.07 & -0.10 & -0.15 & $-0.18 * *$ & $-0.34 * *$ & -0.02 & $-0.29 * * *$ \\
\hline $\mathrm{DA}_{\mathrm{i}, \mathrm{t}-1}$ & $-0.19 * * *$ & $-0.23 * * *$ & $-0.24 * * *$ & $-0.26 * * *$ & $-0.17 * * *$ & $-0.15 * * *$ & $-0.24 * * *$ & $-0.29 * * *$ & $-0.30 * * *$ & $-0.29 * * *$ & $-0.22 * * *$ \\
\hline $\mathrm{LEV}_{\text {it }}$ & $-0.41 * * *$ & $-0.22 * * *$ & $-0.65 * * *$ & $-0.44 * * *$ & $-0.80 * * *$ & $-0.07 * * *$ & $-0.53 * * *$ & $-0.39 * * *$ & $-0.50 * * *$ & $-0.19 * * *$ & $-0.15 * * *$ \\
\hline VOL_INC ${ }_{i t}$ & 0.05 & 0.03 & $0.18 * *$ & 0.03 & 0.19 & $0.12 * *$ & 0.15 & 0.07 & 0.13 & $0.06 * *$ & 0.00 \\
\hline CHAR_INC ${ }_{\text {it }}$ & -0.06 & -0.01 & 0.04 & -0.09 & 0.08 & 0.00 & 0.17 & 0.10 & 0.02 & 0.01 & -0.01 \\
\hline INTERCEPT & 0.96 & 0.46 & 2.25 & 1.42 & 3.56 & 0.43 & 0.31 & -0.34 & 3.91 & 0.32 & 0.45 \\
\hline $\mathrm{N}$ & 393 & 1023 & 372 & 633 & 192 & 510 & 120 & 270 & 162 & 420 & 147 \\
\hline $\mathrm{R}$-square & 0.244 & 0.17 & 0.04 & 0.1023 & 0.0196 & 0.244 & 0.616 & 0.149 & 0.11 & 0.34 & 0.337 \\
\hline $\mathrm{F}$ & 66.38 & 75.47 & 57.54 & 68.26 & 23.66 & 88.59 & 43.29 & 30.70 & 20.67 & 27.72 & 34.79 \\
\hline Prob $>F$ & 0.0000 & 0.0000 & 0.0000 & 0.0000 & 0.0000 & 0.0000 & 0.0000 & 0.0000 & 0.0000 & 0.0000 & 0.0000 \\
\hline
\end{tabular}

$\mathrm{DA}_{\mathrm{it}}$ is the current year's discretionary accrual. EBDA $\mathrm{it}_{\mathrm{it}}$ is earnings before discretionary accruals. EARNINGS $\mathrm{i}_{\mathrm{i}, \mathrm{-}-1}$ is earnings in year t-1 scaled by lagged total assets. $\mathrm{DA}_{\mathrm{i}, \mathrm{t}-1}$ is discretionary accruals in year $\mathrm{t}-1 . \mathrm{LEV}_{\mathrm{it}}$ is total short-term and long-term creditor in year $\mathrm{t}$ scaled by total assets in year t-1. CHAR_INC $\mathrm{it}_{\mathrm{it}}$ is the proportion of charitable income over total income in year $\mathrm{t}$. VOL_ $\mathrm{INC}_{\mathrm{it}}$ is proportion of voluntary income over total income in year $\mathrm{t}$. Size $\mathrm{it}_{\mathrm{it}}$ is the natural logarithm of total assets of charity $\mathrm{i}$ in year $\mathrm{t}$. 
Table 6: Sensitivity analysis results

\begin{tabular}{|c|c|c|}
\hline \multirow[t]{2}{*}{ Variables } & \multirow[t]{2}{*}{ Description } & 2SLS \\
\hline & & Coef. \\
\hline EBDA $_{i t}$ & Earnings before discretionary accruals & $-0.238 * * *$ \\
\hline EARNING $_{i, t-1}$ & Earnings in year t-1 & $0.056 * *$ \\
\hline $\mathbf{D A}_{\mathrm{i}, \mathrm{t}-1}$ & Discretionary accruals in year $\mathrm{t}-1$ & $-0.167 * * *$ \\
\hline $\mathbf{L E V}_{\text {it }}$ & Leverage & $-0.049 * * *$ \\
\hline VOL_INC & Proportion of voluntary income & 0.007 \\
\hline CHAR_INC it & Proportion of charitable income & 0.008 \\
\hline Size & Natural log of total assets of charity $i$ in year $t$. & -0.001 \\
\hline Intercept & & 0.024 \\
\hline $\mathbf{F}$ & & 21.92 \\
\hline Prob > F & & 0.0000 \\
\hline R-square & & 0.1443 \\
\hline
\end{tabular}

Significance at $1 \%$ level (***) and 5\% level (**)

Dependent variable: $\mathrm{DA}_{\mathrm{it}}$ : Discretionary accruals 
Figure 1: Frequency distribution of reported earnings and pre-managed earnings (2009 to $2012, \mathrm{~N}=5656)$

Frequency distribution of reported earnings over lagged total assets

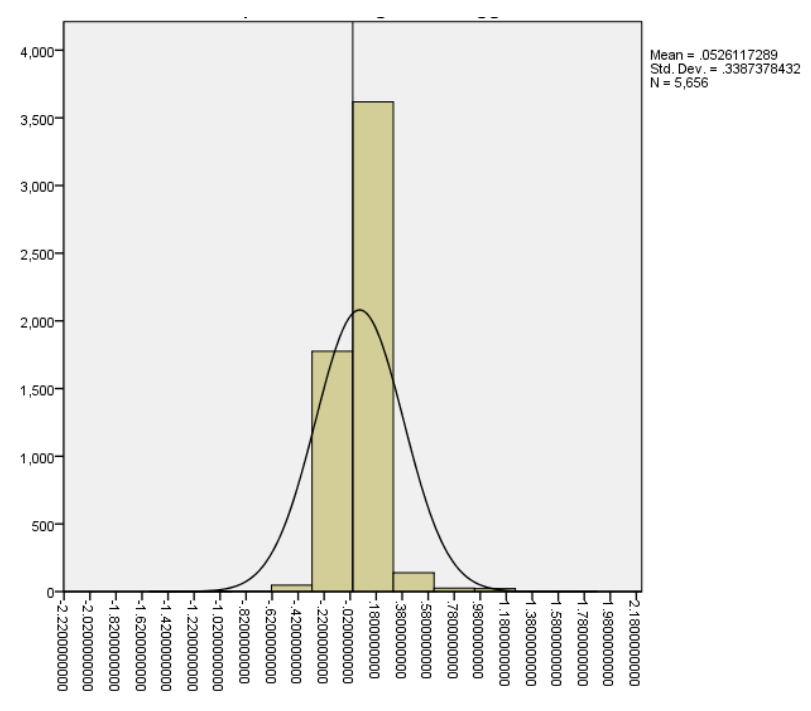

Frequency distribution of pre-managed earnings over lagged total assets

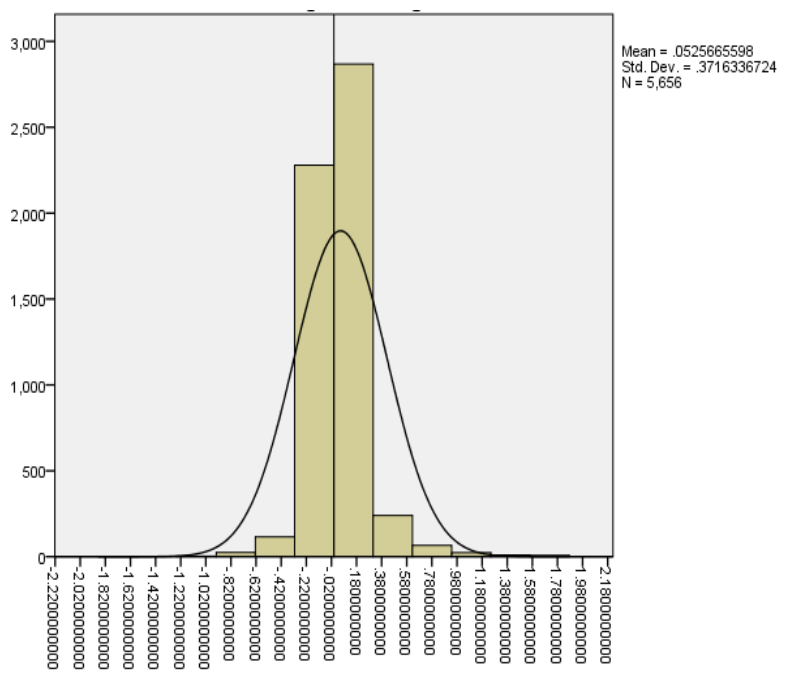

An F-test with null hypothesis was performed to test the differences between means and variances for reported earnings and pre-managed earnings. The results show that the means of reported earnings and un-managed earnings are not significantly different (p-value > 0.05), but the variances of those values are different at a significance level of less than 0.05 . 